\title{
Prehypertensive African-American Women Have Preserved Nitric Oxide and Renal Function but High Cardiovascular Risk
}

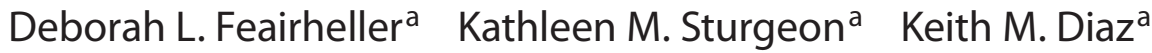 \\ Praveen Veerabhadrappa $^{a}$ Sheara T. Williamson ${ }^{a}$ Deborah L. Crabbe ${ }^{b}$ \\ Michael D. Brown ${ }^{a, c}$ \\ ${ }^{a}$ Hypertension, Molecular and Applied Physiology Laboratory, Department of Kinesiology, Temple University, \\ ${ }^{b}$ Department of Medicine, Division of Cardiology, Temple University Health Sciences Campus, and

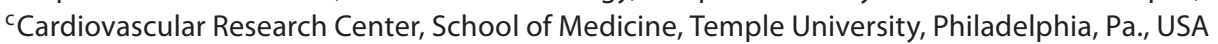

\section{Key Words}

Pre-hypertension $\cdot$ Nitric oxide $\cdot$ High-sensitivity C-reactive protein $\cdot$ African-Americans

\begin{abstract}
Aims: African-Americans, in particular women, exhibit disproportionate levels of hypertension, inflammation, and oxidative stress compared to other ethnic groups. The relationship between prehypertension, renal function, inflammation, and oxidative stress was examined. Methods: Twenty-eight African-American women (53.5 \pm 1.1 years) followed an AHA diet and then underwent 24-hour ambulatory BP (ABP) monitoring. Urinary albumin (uAlb), serum and urinary creatinine, glomerular filtration rate (GFR), 24-hour urinary $\mathrm{Na}^{+}$excretion, plasma superoxide dismutase, total antioxidant capacity (TAC), urinary (uNOx) and plasma (pNOx) nitric oxide levels, and high-sensitivity C-reactive protein (hsCRP) were measured. Results: When the group was divided by average 24-hour ABP into optimal and nonoptimal groups, a significant difference existed between the groups for uNOx ( $p=0.001$; nonoptimal: $933.5 \pm 140.4$, optimal: $425.0 \pm 52.6 \mu \mathrm{mol} / \mathrm{gCr})$, and for hsCRP ( $p=0.018$, nonoptimal: $3.9 \pm 0.7$, optimal: $1.9 \pm 0.6 \mathrm{mg} / \mathrm{l})$. Significant in-
\end{abstract}

verse relationships existed between hsCRP and uNOx and between uAlb and pNOx in the non-optimal group, between GFR and pNOx in the entire group, and positive association existed between TAC and UNOx in the optimal group. Conclusions: These results suggest that in African-American women as BP levels rise toward hypertension, the NO/NOS balance may be associated with renal function, and may have implications for $\mathrm{CV}$ risk based on their hsCRP levels.

Copyright $\odot 2010$ S. Karger AG, Basel

\section{Introduction}

Overall, African-Americans have a $40 \%$ greater prevalence of hypertension (HTN), a higher rate of multiple cardiovascular disease (CVD) risk factors, a 4- to 6-fold greater incidence of end-stage renal disease (ESRD), and the highest overall coronary disease mortality rate of any ethnic group in the United States [1]. In particular, middle-age African-American women are 2-3 times as likely to have HTN as Caucasian women, and HTN is an important causative factor in the lifetime risk for developing heart failure and ESRD [2, 3]. Furthermore, oxidative stress, and inflammation have also been associated with

\section{KARGER}

두 2010 S. Karger AG, Basel

Fax +41613061234 E-Mail karger@karger.ch www.karger.com www.karger.com/kbr
Deborah L. Feairheller

Department of Kinesiology, Temple University

1800 N. Broad Street

Philadelphia, PA 19122 (USA)

Tel. +1 215204 6216, Fax +1 215204 4414, E-Mail dfeairheller@gmail.com 
HTN [4-6]. Recently, plasma levels of high-sensitivity Creactive protein (hsCRP), an acute-phase hepatic protein, have been related to impaired renal function and HTN $[7$, 8]. On the other hand, results from independent studies on the endogenous vasodilator nitric oxide (NO) conflict because some studies suggest a deficiency in NO with ESRD and HTN [9], while others report upregulated NO production [10]. NO serves as a potent vasodilator that is produced through oxidation of L-arginine to L-citrulline and released from the endothelial layer of blood vessels [11]. Vascular NO levels serve to maintain endothelial function either mechanically through augmented smooth muscle relaxation, or chemically through the rapid inactivation of the superoxide radical $\left(\mathrm{O}_{2}\right)$ [12]. In fact, within the renal system, NO exerts a powerful influence on the regulation of glomerular filtration rate (GFR) and sodium $\left(\mathrm{Na}^{+}\right)$excretion [13].

Pre-hypertension (PHTN) is known to be a predictor for the future development of HTN. PHTN is a blood pressure (BP) classification defined by the Joint National Committee on Prevention, Detection, Evaluation, and Treatment of High Blood Pressure (JNC 7) as systolic BP between 120 and $139 \mathrm{~mm} \mathrm{Hg}$ and diastolic BP between 80 and $89 \mathrm{~mm} \mathrm{Hg}$ [14]. Individuals with PHTN are likely to develop HTN within 5 years, yet the factors involved in this transition remain unclear. The impact of PHTN in African-American women on the development of ESRD and subsequent CVD progression may be substantial, since African-Americans are more likely to develop PHTN at younger ages and its presence is associated with future atherosclerosis [15]. Data from the Women's Health Initiative Study suggests that women with PHTN are at increased risk for CVD events [16]. Recently, a few population-based studies have reported that the risk of renal disease may extend to PHTN, but defining the BP levels at which this risk exists needs to be determined [17-19]. Furthermore, the physiologic derangements associated with impaired renal function as seen in HTN may occur earlier during the period of PHTN and are likely to involve increased oxidative stress and inflammation as seen in frank HTN. Despite this plausibility, the relationship between BP levels in the PHTN range, renal function, inflammation, and oxidative stress remains to be fully established.

It has been suggested that using 24-hour ambulatory $\mathrm{BP}(\mathrm{ABP})$ monitoring better predicts the risk of morbid events than clinical BP measurements because a 24 -hour average considers the pressure load on the blood vessel system over an entire 24-hour period [20]. From this, BP values have been suggested that define the upper limits of ABP averages. 'Optimal' 24-hour average BP values are
$<125 / 75$, 'normal' 24-hour average BP values are $<130 / 80$, and 'abnormal' 24-hour average BP values are $>135 / 85$ [21]. The PHTN classification range of BP by JNC 7 (systolic BP $120-139 \mathrm{~mm} \mathrm{Hg}$ or diastolic BP $80-89 \mathrm{~mm} \mathrm{Hg}$ ) includes a larger range of $\mathrm{BP}$ values than those that fall primarily in the 'normal' 24 -hour average $\mathrm{BP}$ range. Considering this, we used average 24-hour ABP values obtained through ABP monitoring to classify participants into BP groups in order to better compare potential effects that a PHTN BP may have on renal function and oxidative stress markers in African-American women.

The purpose of our study was to compare several indices of renal function with urinary (uNOx) and plasma (pNOx) NO levels, the plasma antioxidant biomarkers superoxide dismutase (SOD) and total antioxidant capacity (TAC), and the inflammatory marker hsCRP, in AfricanAmerican women with both optimal and nonoptimal average 24-hour ABP levels.

\section{Materials and Methods}

This study included pre- and post-menopausal African-American women $(n=28)$ between the ages of $40-75$ years $(53.5 \pm 1)$ who were sedentary, nonsmokers, nondiabetics, not on lipid-lowering medications, had an average BMI of $32.1 \pm 1$, were on no more than one antihypertensive medication, and were without any end-organ damage. Participants responded to media advertisements and underwent a telephone interview to assess their initial eligibility. The study was approved by the Institutional Review Board of Temple University, Philadelphia, Pa., USA. All participants provided their written, informed consent during their first laboratory visit. None of the women were on a hormone replacement therapy regimen. Medical histories were reviewed on the first laboratory visit to ensure they met the study inclusion criteria listed above.

A 12-hour overnight fasting blood sample was drawn for blood chemistry, complete blood count, lipid profiles, serum creatinine (SCr), and hsCRP levels. Glomerular filtration rate (GFR) was calculated using the 4-variable MDRD equation specific to African-Americans: GFR $\left(\mathrm{ml} / \mathrm{min} / 1.73 \mathrm{~m}^{2}\right)=186 \times\left(\mathrm{SCr}^{-1.154}\right)^{*}$ $\left(\text { age }^{-0.203}\right)^{*}(1.21)^{*}(0.742$ if female $)$ [22]. Participants then underwent a physical examination and a physician-supervised echocardiogram bicycle stress test to screen for any cardiovascular, pulmonary, or other chronic diseases. All qualified participants then underwent 6 weeks of dietary instruction ( $1 \mathrm{~h}$ each session) with a registered dietician instructing them on how to maintain the American Heart Association low-fat ( $<30 \%$ total calorie intake) and low-sodium ( $<3 \mathrm{~g} /$ day $)$ diet. Participants had to follow this prescribed diet continuously throughout the dietary instruction period and be weight stable before undergoing any testing. Under close supervision of the study physician, any woman using one antihypertensive medication was tapered off the medication and remained off of their medication for the duration of the study. At the completion of the 6 weeks, a submaximal treadmill (TM) exercise test was performed to measure the volume of oxygen con- 
sumption $\left(\mathrm{VO}_{2}\right)$. The TM test was terminated when participant reached $75-80 \%$ of their estimated heart rate reserve. Regression analysis using data collected by indirect calorimetry was used to predict $\mathrm{VO}_{2 \max }$ levels.

\section{Measurement of Plasma (pNOx) and Urinary Nitrates/ Nitrites $(u N O x)$}

Levels of NO end-products were measured using a modified Griess assay. Blood samples were collected in $\mathrm{K}_{2}$ EDTA tubes, centrifuged at $2,000 \mathrm{~g}$ for $20 \mathrm{~min}$ at $4^{\circ} \mathrm{C}$, and then the plasma was frozen at $-80^{\circ} \mathrm{C}$ until assay. On the day of assay, plasma samples were ultrafiltered through a 10,000 MWCO Amicon Ultra filter (Millipore) by micro-centrifuge at $14,000 \mathrm{~g}$ for $30 \mathrm{~min}$ at $4^{\circ} \mathrm{C}$. Urine was aliquoted from the total-volume 24 -hour urine collection and frozen at $-80^{\circ} \mathrm{C}$ until assay. All urine samples were diluted 1:10 in reaction buffer (HEPES based). Briefly, the assay involves an enzymatic conversion of nitrate to nitrite by nitrate reductase (Aspergillus species) followed by measurement of nitrite through formation of a magenta-colored azo dye as a product of a Griess reaction. The Griess reagents used were N-(1-naphthyl)ethylenediamine in $2 \mathrm{M}$ hydrochloric acid and sulfanilamide in $2 \mathrm{M}$ hydrochloric acid. Absorbance was read at $540 \mathrm{~nm}$ using a SpectraMax Microplate Reader (Molecular Devices, Sunnyvale, Calif., USA). All reagents used were obtained from Assay Designs (Ann Arbor, Mich., USA). Inter-assay and intra-assay CVs were 7.6 and $10.6 \%$, respectively.

\section{Measurement of Plasma Superoxide Dismutase}

Superoxide dismutase (SOD) activity was determined using a commercially available kit (Cayman Chemical, Ann Arbor, Mich., USA). Blood samples were collected in sodium-heparin tubes, centrifuged at $2,000 \mathrm{~g}$ for $20 \mathrm{~min}$ at $4^{\circ} \mathrm{C}$, and then the plasma was frozen at $-80^{\circ} \mathrm{C}$ until assay. Plasma samples were diluted 1:5 in sample buffer (50 mM Tris- $\mathrm{HCl}, \mathrm{pH} 8.0)$. SOD activity was measured by utilizing a tetrazolium salt radical detector solution, diluted in assay buffer $(50 \mathrm{mM}$ Tris- $\mathrm{HCl}, \mathrm{pH} 8.0$, containing $0.1 \mathrm{~mm}$ diethylenetriaminepentaacetic acid and 0.1 $\mathrm{mM}$ hypoxanthine), to detect superoxide radicals generated by hypoxanthine and xanthine oxidase. One unit of SOD activity is defined as the amount of enzyme needed to exhibit a $50 \%$ dismutation of the superoxide radical. Absorbance was read at 450 nm using a SpectraMax Microplate Reader (Molecular Devices). The detection limit of the kit was $0.025 \mathrm{U} / \mathrm{ml}$. Inter-assay and intra-assay coefficients of variation were 5.9 and $12.4 \%$, respectively.

\section{Measurement of Total Antioxidant Capacity}

Total antioxidant capacity (TAC) activity was determined using a commercially available kit (Cayman Chemical). Blood samples were collected in sodium-heparin tubes, centrifuged at $2,000 \mathrm{~g}$ for $20 \mathrm{~min}$ at $4^{\circ} \mathrm{C}$, and then the plasma was frozen at $-80^{\circ} \mathrm{C}$ until assay. Plasma samples were diluted 1:20 in assay buffer $(5 \mathrm{~mm}$ potassium phosphate, $\mathrm{pH} 7.4$, containing $0.9 \%$ sodium chloride and $0.1 \%$ glucose). TAC measurement was based on the ability of antioxidants in the plasma to inhibit the oxidation of $\operatorname{ABTS}^{\circledR}\left(2,2^{\prime}\right.$-azino-di- to ABTS by metmyoglobin). The capacity of the antioxidants in plasma to prevent ABTS oxidation is compared with that of a water-soluble vitamin E analogue, Trolox. Absorbance was read at $750 \mathrm{~nm}$ using a SpectraMax Microplate Reader (Molecular Devices), and TAC activity quantified as mil- limolar Trolox equivalents. The detection limit of the kit was $0.044 \mathrm{~mm}$. Inter-assay and intra-assay coefficients of variation were 6.7 and $9.2 \%$, respectively.

\section{Ambulatory BP Monitoring and Urine Collection}

Participants underwent ABP using a noninvasive monitor (SpaceLabs Medical Inc., Model 90219, Redmond, Wash., USA) beginning on the morning of a typical day, with the exclusion of Friday through Sunday. The BP cuff was fitted to the participant's non-dominate arm with cuff size determined by upper arm circumference. BP measurements were obtained at 30-min intervals during the day (6.00 a.m. to 10.00 p.m.) and 60-min intervals at night (10 p.m. to 6 a.m.). Participants were instructed not to exercise prior to or during the 24-hour ABP monitoring period and to pause momentarily and maintain their body position during each BP measurement. From this, we used the average 24-hour ABP values to classify participants in our study into BP groups. Due to the fact that some of the participants were initially on one antihypertensive medication which was stopped before inclusion into the study, we defined the BP groups for this study based on ABP categories. Any participant with 24-hour average ABP <125/75 were placed into the 'optimal' group, while any participant with 24-hour average ABP $>125 / 75$ was placed into a 'nonoptimal' group. This was in order to compare potential BP effect on renal function, inflammation, and oxidative stress levels in AfricanAmerican women.

Total volume of urine collected over the same 24-hour period was measured and recorded. Samples of 24-hour urine were then aliquoted and sent to Quest Diagnostics for measurement of urinary creatinine (UCr), urinary sodium $(\mathrm{Na})$, and urinary albumin (uAlb) levels. From this data, creatinine clearance $(\mathrm{CrCl}) \mathrm{ra}-$ tio was calculated: $\mathrm{CrCl}(\mathrm{ml} / \mathrm{min})=(\mathrm{UCr} \times 24$-hour urine volume) $/ \mathrm{SCr} \times 24 \times 60 \mathrm{~min}$.

\section{Statistical Analysis}

Data are presented as means \pm SE and significance was set at $\mathrm{p}<0.05$. The distribution of all variables was examined using the Shapiro-Wilk test of normality, and homogeneity of variances was determined using Levene's test. Variables that were found to fail the normality test were log adjusted for any statistical analysis, but true physiological values of any variable are reported. Independent $t$-tests and ANOVA were used to determine if there were significant differences between BP groups (optimal and non-optimal). Pearson correlation was used to determine if there were relationships between variables. All variables with $p<0.05$ in the Pearson correlation analyses were examined by linear regression analysis. Data was further analyzed using MANOVA and covarying for menopause status, BMI, age, and prior BP medication usage. All statistical analyses were performed using SPSS version 17.0 (SPSS Inc., Chicago, Ill., USA).

\section{Results}

Twenty-eight African-American women, age $53 \pm 1$ years, participated in this study. Table 1 shows subject characteristics divided by BP group. HDL-C was significantly different between groups, with the optimal group 
Fig. 1. Blood pressure group differences in $\mathrm{uNOx}(\mathbf{a})$ and hsCRP (b). uNOx = Urinary nitric oxide metabolites; hsCRP = highsensitivity C-reactive protein. Values are mean $\pm \mathrm{SE}$. ${ }^{*} \mathrm{p}<0.05$ between blood pressure groups.

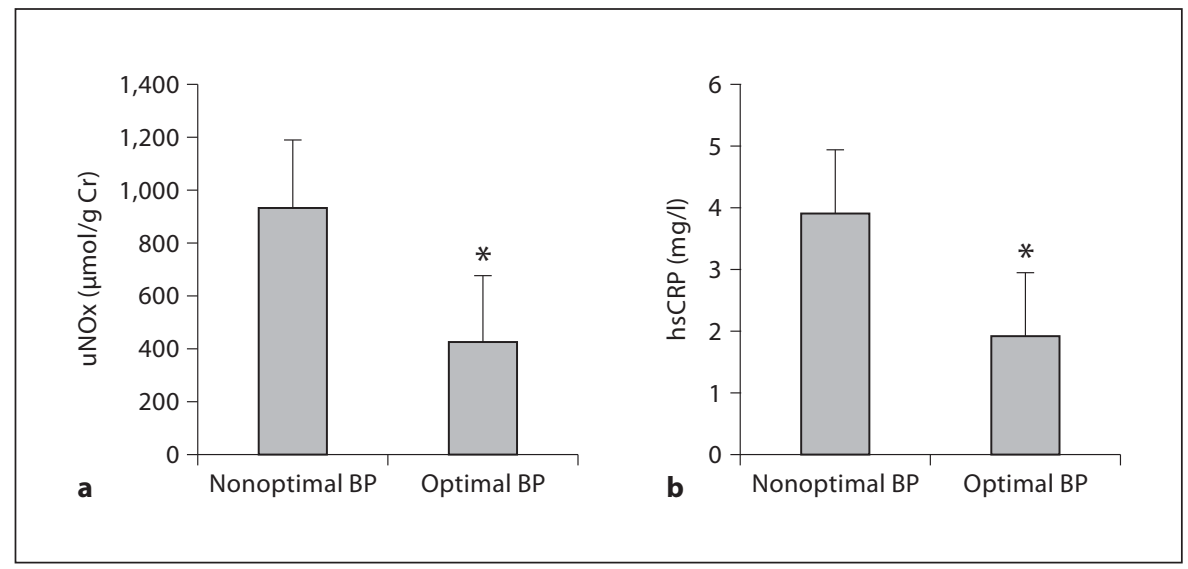

Table 1. Subject characteristics by blood pressure group

\begin{tabular}{|c|c|c|c|}
\hline & $\begin{array}{l}\text { Optimal } \\
(\mathrm{n}=14)\end{array}$ & $\begin{array}{l}\text { Nonoptimal } \\
(\mathrm{n}=14)\end{array}$ & $\begin{array}{l}\mathrm{p} \\
\text { value }\end{array}$ \\
\hline Age, years & $53.9 \pm 1.6$ & $53.0 \pm 1.7$ & 0.69 \\
\hline BMI & $32.4 \pm 1.5$ & $31.9 \pm 1.4$ & 0.79 \\
\hline Total cholesterol, mg/dl & $195.3 \pm 6.7$ & $191.0 \pm 7.6$ & 0.67 \\
\hline HDL-C, mg/dl & $71.0 \pm 4.6$ & $57.0 \pm 2.9$ & $0.02^{*}$ \\
\hline $\mathrm{LDL}-\mathrm{C}, \mathrm{mg} / \mathrm{dl}$ & $108.9 \pm 8.1$ & $114.4 \pm 6.8$ & 0.61 \\
\hline Triglycerides, mg/dl & $75.8 \pm 5.4$ & $97.3 \pm 11.8$ & 0.11 \\
\hline $\mathrm{VO}_{2 \max }, \mathrm{ml} / \mathrm{kg} / \mathrm{min}$ & $25.3 \pm 1.5$ & $24.3 \pm 0.9$ & 0.59 \\
\hline Fasting glucose, $\mathrm{mg} / \mathrm{dl}$ & $95.0 \pm 3.1$ & $93.1 \pm 2.1$ & 0.61 \\
\hline WBC count, million $/ \mu \mathrm{l}$ & $5.4 \pm 0.4$ & $5.2 \pm 0.5$ & 0.65 \\
\hline hsCRP, mg/l & $1.9 \pm 0.57$ & $3.9 \pm 0.72$ & $0.02^{*}$ \\
\hline \multicolumn{4}{|c|}{ Average 24-hour BP, mm Hg } \\
\hline Systolic BP & $116.3 \pm 1.7$ & $133.8 \pm 1.9$ & $0.00^{*}$ \\
\hline Diastolic BP & $71.5 \pm 1.9$ & $81.3 \pm 1.5$ & $0.00^{*}$ \\
\hline
\end{tabular}

Data are presented as mean \pm SE. $n=$ Sample size; $\mathrm{BMI}=$ body mass index; HDL-C = high-density lipoprotein cholesterol; LDL$\mathrm{C}=$ low-density lipoprotein $\mathrm{VO}_{2 \max }=$ maximum oxygen consumption; $\mathrm{WBC}=$ white blood cell; hsCRP = high-sensitivity Creactive protein; $\mathrm{BP}=$ blood pressure.

* Denotes significant difference between groups.

having higher levels $(71.0 \pm 4.6$ compared to $57.0 \pm 2.9$, $\mathrm{p}=0.02)$. No significant differences existed between groups for any of the other characteristics, except for hsCRP which was higher in the nonoptimal BP group (3.9 \pm 0.72 compared to $1.9 \pm 0.57, \mathrm{p}=0.02$ ), as seen in figure $1 \mathrm{~b}$. Table 2 shows the oxidative stress and renal function variables for the participants divided by BP group. The only variable that was significantly different between groups was uNOx, as seen in figure 1a. The women with nonoptimal BP had significantly higher levels of uNOx
Table 2. Oxidative stress and renal characteristics by blood pressure group

\begin{tabular}{lccl}
\hline & $\begin{array}{l}\text { Optimal } \\
(\mathrm{n}=14)\end{array}$ & $\begin{array}{l}\text { Nonoptimal } \\
(\mathrm{n}=14)\end{array}$ & $\begin{array}{l}\mathrm{p} \\
\text { value }\end{array}$ \\
\hline $\mathrm{SOD}, \mathrm{U} / \mathrm{ml}$ & $4.9 \pm 1.1$ & $3.7 \pm 0.7$ & 0.75 \\
$\mathrm{TAC}, \mathrm{mm}$ & $2.3 \pm 0.5$ & $2.6 \pm 0.4$ & 0.62 \\
$\mathrm{uNOx}, \mu \mathrm{mol} / \mathrm{g} \mathrm{Cr}$ & $425.0 \pm 52.6$ & $933.5 \pm 140.4$ & $0.001^{*}$ \\
$\mathrm{pNOx}, \mu \mathrm{mol} / \mathrm{l}$ & $22.6 \pm 3.7$ & $22.6 \pm 3.9$ & 0.97 \\
$\mathrm{TV}, \mathrm{ml}$ & $1,644.3 \pm 287.3$ & $1,947.7 \pm 173.9$ & 0.38 \\
$\mathrm{Na}, \mathrm{mmol} / \mathrm{g} \mathrm{Cr}$ & $83.2 \pm 9.7$ & $102.6 \pm 9.2$ & 0.16 \\
Urinary creatinine, g/24 h & $1.6 \pm 0.1$ & $1.4 \pm 0.1$ & 0.39 \\
Urinary albumin, $\mathrm{mg} / 24 \mathrm{~h}$ & $9.2 \pm 1.8$ & $14.4 \pm 4.0$ & 0.26 \\
Serum creatinine, $\mathrm{mg} / \mathrm{dl}$ & $0.85 \pm 0.03$ & $0.83 \pm 0.04$ & 0.72 \\
GFR, $\mathrm{ml} / \mathrm{min} / 1.73 \mathrm{~m}{ }^{2}$ & $91.2 \pm 3.3$ & $96.8 \pm 5.7$ & 0.41 \\
CrCl ratio, $\mathrm{ml} / \mathrm{min} / 1.73 \mathrm{~m}{ }^{2}$ & $129.5 \pm 10.9$ & $124.6 \pm 12.8$ & 0.77 \\
\hline
\end{tabular}

Data are presented as mean \pm SE. $\mathrm{n}=$ Sample size; $\mathrm{SOD}=\mathrm{su}-$ peroxide dismutase activity; TAC = total antioxidant capacity; $\mathrm{uNOx}=$ urinary nitric oxide metabolites; $\mathrm{pNOx}=$ plasma nitric oxide metabolites; TV = total 24 -hour urine volume; $\mathrm{Na}=$ urinary sodium; GFR = glomerular filtration rate; $\mathrm{CrCl}=$ creatinine clearance ratio.

* Denotes significant difference between groups.

(933.5 $\pm 140.4 \mu \mathrm{mol} / \mathrm{g}$ Cr compared to $425.0 \pm 52.6$ $\mu \mathrm{mol} / \mathrm{g} \mathrm{Cr}, \mathrm{p}=0.001)$.

Correlation and regression analyses showed several significant associations between oxidative stress and renal function markers. For the entire group, a significant inverse relationship existed between GFR and pNOx $(\mathrm{r}=$ $0.411, \mathrm{p}=0.030$ ), as seen in figure 2. Sub-analysis of the nonoptimal BP group revealed significant inverse relationships between hsCRP and $\mathrm{uNOx}(\mathrm{r}=0.660, \mathrm{p}=0.019)$, and between $\mathrm{uAlb}$ and $\mathrm{pNOx}(\mathrm{r}=0.566, \mathrm{p}=0.035)($ fig. 3$)$. 


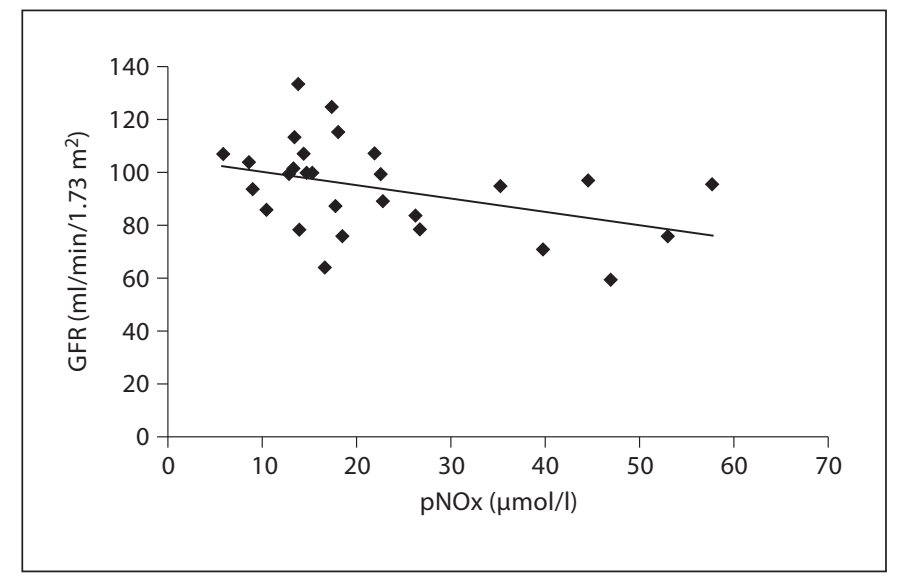

Fig. 2. Regression analysis between GFR and $\mathrm{pNOx}(\mathrm{r}=0.411, \mathrm{p}=$ $0.030)$. GFR = Glomerular filtration rate; $\mathrm{pNOx}=$ plasma nitric oxide metabolites.

Finally, as shown in figure 4 , there was a significant positive association between TAC and $\mathrm{uNOx}(\mathrm{r}=0.549, \mathrm{p}=$ 0.042) in the participants with optimal BP.

\section{Discussion}

To the best of our knowledge, this study is the first to report increased uNOx levels in a group of AfricanAmerican women with nonoptimal BP levels, similar to PHTN BP levels, compared to women with optimal BP levels. Our results confirm in humans what has been established by molecular studies in animal models. We found a significantly higher level of uNOx in women with elevated BP levels. We found no significant difference in pNOx levels, SOD activity, or TAC between groups. Our results suggest that a NO/NOS imbalance may exist within the renal system in African-American women with elevated BP, but that these BP levels may not elicit an imbalance in pNOx or plasma antioxidant activity.

Data on the relationship between renal function, HTN, and NO production are conflicting. Although studies have reported depressed NO production with essential HTN or with renal impairment, others have suggested that an increase in NO activity occurs. For example, Schmidt and Baylis [23] reported that uNOx levels were lower in chronic renal dialysis patients than in healthy individuals. Likewise, Kim et al. [24] found a significantly lower uNOx production in the kidneys of rats with chronic renal failure but found no significant difference in $\mathrm{pNOx}$ levels between the renal failure rats and normal

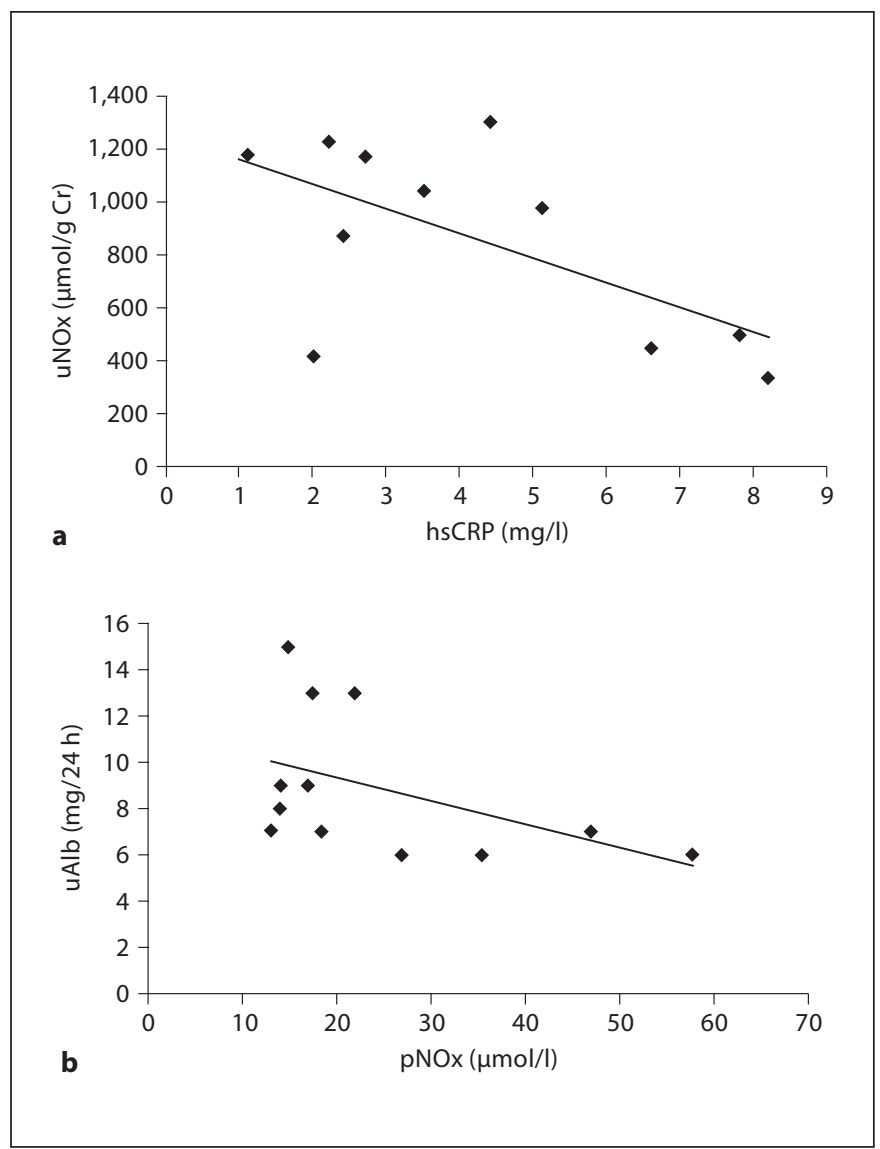

Fig. 3. Regression analyses in the non-optimal blood pressure group. a hsCRP with uNOx $(\mathrm{r}=0.660, \mathrm{p}=0.019)$. b uAlb with $\mathrm{pNOx}(\mathrm{r}=0.566, \mathrm{p}=0.035)$. hsCRP $=$ High-sensitivity C-reactive protein; $\mathrm{uNOx}=$ urinary nitric oxide metabolites; $\mathrm{uAlb}=$ urinary albumin; $\mathrm{pNOx}=$ plasma nitric oxide metabolites.

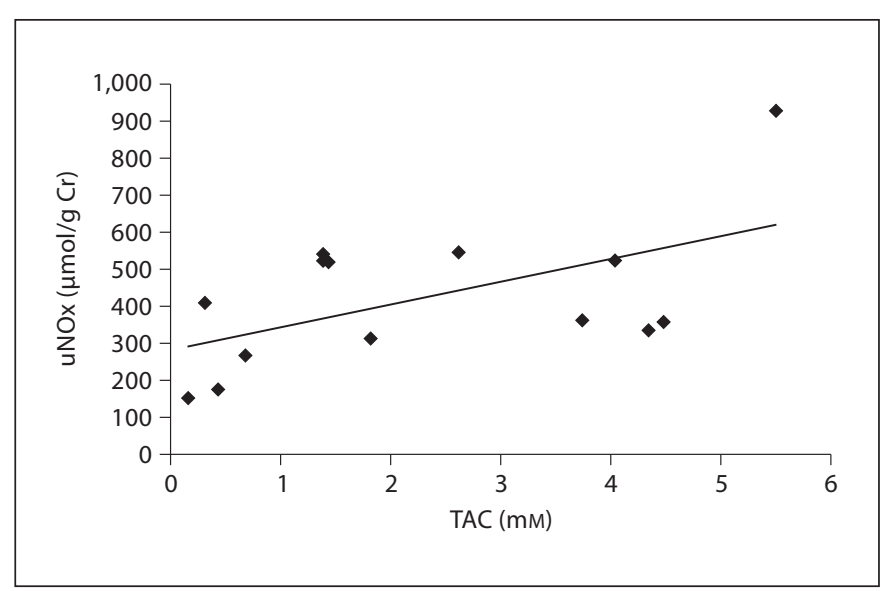

Fig. 4. Optimal blood pressure group regression analysis between TAC and uNOx $(\mathrm{r}=0.549, \mathrm{p}=0.042)$. TAC $=$ Total antioxidant activity; $\mathrm{uNOx}=$ urinary nitric oxide metabolites. 
rats. In contrast, other research supports increased NO production. Lyamina et al. [25] found that uNOx levels were increased in young individuals with BP in the PHTN range (137 $\pm 3.2 / 88 \pm 1.9 \mathrm{~mm} \mathrm{Hg})$, leading authors to suggest that elevations in uNOx levels may be a compensatory response to the rising $\mathrm{BP}$. This result is similar to our findings.

Generation of NO occurs by three nitric oxide synthase (NOS) enzyme isoforms. Two, endothelial NOS (eNOS) and neuronal NOS (nNOS), are constitutive and continuously produce low levels of NO. The third NOS isoform is inducible (iNOS) and activated in response to cellular stress, toxins, and cytokines [26]. When iNOS activity is increased, it produces close to 1,000 times more NO than eNOS or nNOS, and this cellular iNOSmediated NO production can continue for hours [27, 28]. Impaired NO production variably affects endothelial function in systemic and renal blood vessels depending on the NOS isoform affected. Further supporting the view that $\mathrm{NO}$ production may be augmented during the early stages of HTN are several recent molecular biology studies that provide mechanistic evidence by showing overall increased NO production in SHR. Vaziri et al. used young SHR in order to attempt to discern the effects of PHTN on NO metabolism and reported significant increases in uNOx, eNOS, and iNOS [29]. Kumar et al. reported an overproduction of iNOS in the cortex, inner medulla, and proximal tubules of SHR [30]. They also separately showed that $\mathrm{eNOS}$ and nNOS expressions were decreased in the inner medulla and renal cortex [31]. The authors concluded that an imbalance in $\mathrm{NO} / \mathrm{NOS}$ system exists in the SHR kidney. Likewise, Suzuki et al. [32] used the one-clamp model in adult Wistar-Kyoto rats and Dubey et al. [33] used one-kidney, one-clip HT rats, and both reported that increased NO production accompanied the early rise in BP. These studies indicate that the delicate balance of NO production from specific NOS isoforms may affect the quantitative measurement of the total circulating NO metabolites. Furthermore, they also showed that early rises in BP, such as that seen with PHTN, may have different effects on NO production than that found in established essential HTN. Research in humans with varying levels of $\mathrm{BP}$ is necessary to elucidate the role of NO metabolism in the transition from normal BP to PHTN and then to HTN.

Another important finding from our study was that the African-American women with nonoptimal BP levels had significantly higher hsCRP levels compared to those with optimal BP levels. The American Heart Association and the Centers for Disease Control define hsCRP risk categories as $<1 \mathrm{mg} / \mathrm{l}$ is low risk, $1-3 \mathrm{mg} / \mathrm{l}$ is average risk, and $>3 \mathrm{mg} / \mathrm{l}$ is high risk [34]. Our nonoptimal group had hsCRP levels that fall in the high-risk category with an average of $3.9 \mathrm{mg} / \mathrm{l}$. The biomarker hsCRP has consistently been associated with HTN, CVD and atherosclerosis [35-38]. Our data extends this further by suggesting that hsCRP may have association with BP levels in the PHTN range. In particular, in relation to women, Ridker et al. [39] found that hsCRP was a strong significant predictor of risk for future cardiovascular events in women. And furthermore, African-American women have been reported to have the highest levels of hsCRP compared to other ethnic groups [40]. Interestingly, in our study, within group analysis revealed inverse relationships between hsCRP and uNOx levels in both groups, but the correlation was only significant in the nonoptimal, higher BP, group. Other studies have provided evidence confirming such an association. Verma et al. [41] used cultured endothelial cells to show that high concentrations of hsCRP reduces eNOS activity, decreases eNOS mRNA stability, and quenches NO production. Separately, Venugopal also tested the effect of CRP on eNOS expression and activity and found a direct reduction in eNOS activity [42]. Our results support these findings by reporting that AfricanAmerican women with non-optimal BP levels exhibit an inverse association between hsCRP and uNOx. Taken together, despite significantly higher levels of both uNOx and hsCRP in women with nonoptimal BP levels, it seems plausible that the high hsCRP levels may be affecting eNOS stability and thus creating an inverse association within this group.

We also found an inverse correlation between uAlb excretion and $\mathrm{pNOx}$ within both groups, again with significance found only in the nonoptimal BP group. Increased uAlb excretion is a key marker for diagnosing renal dysfunction and has been associated with increased risk of CVD [43]. Although both groups had uAlb excretion levels within normal limits, higher uAlb levels were significantly correlated with lower pNOx in the women with non-optimal BP levels. This correlation suggests that African-American women with nonoptimal BP levels, suggestive of PHTN, who have higher uAlb levels and therefore tend towards renal dysfunction have lower pNOx activity. It has been previously reported that elevated uAlb levels in healthy adults were associated with impaired arterial vasodilatory capacity as measured by pNOx [44]. Our study provides support for this in African-American women.

GFR, as estimated by the 4 -variable MDRD equation, continues to be a key diagnostic marker of renal function. 
Measuring the volume of fluid filtered through the renal cavity per unit time, GFR gives a relative indicator of filtering capacity in the kidneys. While the average GFR for our nonoptimal group was higher than that of the optimal group, the difference between groups was not statistically different. When the entire group was combined, there was a significant inverse correlation between $\mathrm{pNOx}$ and GFR. It is speculated that participants with lower GFR levels may have some compensatory mechanism leading to higher pNOx levels.

Participants in the present study were tapered from their anti-hypertensive medication and were studied after a minimum of 3 weeks without medication use. However, long-term use of anti-hypertensive medication may affect factors involved in BP and renal regulation. In addition, albuminuria and GFR may influence BP responses to antihypertensive drug therapy [45]. It is recognized that some antihypertensive medications are effective at improving endothelial function as well as reducing BP, yet evidence is limited whether the pharmacologically induced improvement is transient or permanent $[46,47]$. Interestingly, in our study, $\mathrm{SCr}(\mathrm{p}=0.035)$ and GFR $(\mathrm{p}=$ 0.04 ) were significantly different between $\mathrm{BP}$ groups after covarying for prior antihypertensive medication usage, indicating a potential interaction between GFR and BP responses to long-term antihypertensive medication use. Further research needs to be conducted to examine the potential long-term effects of antihypertensive medication on renal function.

Finally, our within-group analyses showed that in the optimal BP group, plasma TAC was significantly and positively correlated with uNOx. It has been shown that HTN individuals have lower antioxidant activity [48, 49], in particular a reduction in TAC [50]. This may extend to PHTN BP levels and may explain why no correlation was observed in our nonoptimal group.
It must be noted that there are some limitations to our study. First, our sample size is small, but this was due to the exclusion of diabetics, smokers, women on more than one antihypertensive medication, and women with cardiovascular disease. This was intentionally done in order to create as homogenous group as possible and to ensure lack of confounding variables that may influence renal function or oxidative stress measures. Second, only associations are reported, not causations; however, we provide strong support for each of our findings from mechanistic studies in animal or cell models. Finally, only antioxidant variables were included in this study. Future research should include other oxidative stress biomarkers to better understand the physiological association between $\mathrm{NO}$ levels and renal function.

In conclusion, our data report that African-American women with nonoptimal BP levels, representative of PHTN BP levels, have higher uNOx production, higher levels of hsCRP, and exhibit significant inverse correlations between renal function measures and NO metabolism when compared to African-American women with normal BP levels, who had a positive association between TAC and NO production. Together, these results suggest that in African-American women the NO/NOS balance may be associated with renal function, and that AfricanAmerican women with BP levels in the PHTN range may have significant cardiovascular risk.

\section{Acknowledgements}

This research was supported by NIH/NHLBI Grant RO1 HL085497 (PI, Michael Brown) and by NIH/NIA Grant KO1 AG019640 (PI, Michael Brown).

\section{References}

1 Hsu CY, Lin F, Vittinghoff E, Shlipak MG: Racial differences in the progression from chronic renal insufficiency to end-stage renal disease in the United States. J Am Soc Nephrol 2003; 14:2902-2907.

- 2 Ho KK, Pinsky JL, Kannel WB, Levy D: The epidemiology of heart failure: the Framingham Study. J Am Coll Cardiol 1993;22:6A$13 \mathrm{~A}$.
Lloyd-Jones DM, Sutton-Tyrrell K, Patel AS, Matthews KA, Pasternak RC, Everson-Rose SA, Scuteri A, Chae CU: Ethnic variation in hypertension among premenopausal and perimenopausal women: Study of Women's Health Across the Nation. Hypertension 2005;46:689-695.

-4 Hsu CY, McCulloch CE, Darbinian J, Go AS, Iribarren C: Elevated blood pressure and risk of end-stage renal disease in subjects without baseline kidney disease. Arch Intern Med 2005; 165:923-928.

\footnotetext{
Tonelli M, Sacks F, Pfeffer M, Jhangri GS, Curhan G: Biomarkers of inflammation and progression of chronic kidney disease. Kidney Int 2005;68:237-245.

-6 Stam F, van Guldener C, Schalkwijk CG, ter Wee PM, Donker AJ, Stehouwer CD: Impaired renal function is associated with markers of endothelial dysfunction and increased inflammatory activity. Nephrol Dial Transplant 2003;18:892-898.
} 
7 Annuk M, Soveri I, Zilmer M, Lind L, Hulthe J, Fellstrom B: Endothelial function, CRP and oxidative stress in chronic kidney disease. J Nephrol 2005;18:721-726.

$\checkmark 8$ Bautista LE, Lopez-Jaramillo P, Vera LM, Casas JP, Otero AP, Guaracao AI: Is C-reactive protein an independent risk factor for essential hypertension? J Hypertens 2001;19: 857-861.

-9 Landmesser U, Dikalov S, Price SR, McCann L, Fukai T, Holland SM, Mitch WE, Harrison DG: Oxidation of tetrahydrobiopterin leads to uncoupling of endothelial cell nitric oxide synthase in hypertension. J Clin Invest 2003; 111:1201-1209.

-10 Maffei A, Poulet R, Vecchione C, Colella S, Fratta L, Frati G, Trimarco V, Trimarco B, Lembo G: Increased basal nitric oxide release despite enhanced free radical production in hypertension. J Hypertens 2002;20: 1135-1142.

-11 ArnalJF, Dinh-Xuan AT, Pueyo M, Darblade B, Rami J: Endothelium-derived nitric oxide and vascular physiology and pathology. Cell Mol Life Sci 1999;55:1078-1087.

- 12 Moncada S, Palmer RM, Higgs EA: Nitric oxide: physiology, pathophysiology, and pharmacology. Pharmacol Rev 1991;43:109142 .

-13 Modlinger PS, Wilcox CS, Aslam S: Nitric oxide, oxidative stress, and progression of chronic renal failure. Semin Nephrol 2004; 24:354-365.

-14 Chobanian AV, Bakris GL, Black HR, Cushman WC, Green LA, Izzo JL Jr, Jones DW, Materson BJ, Oparil S, Wright JT Jr, Roccella EJ: The Seventh Report of the Joint National Committee on Prevention, Detection, Evaluation, and Treatment of High Blood Pressure: the JNC 7 report. JAMA 2003;289: 2560-2572.

-15 Pletcher MJ, Bibbins-Domingo K, Lewis CE, Wei GS, Sidney S, Carr JJ, Vittinghoff E, McCulloch CE, Hulley SB: Prehypertension during young adulthood and coronary calcium later in life. Ann Intern Med 2008;149: 91-99.

-16 Hsia J, Margolis KL, Eaton CB, Wenger NK, Allison M, Wu L, LaCroix AZ, Black HR: Prehypertension and cardiovascular disease risk in the Women's Health Initiative. Circulation 2007;115:855-860.

-17 Reynolds K, Gu D, Muntner P, Kusek JW, Chen J, Wu X, Duan X, Chen CS, Klag MJ, Whelton $\mathrm{PK}, \mathrm{He} \mathrm{J}$ : A population-based, prospective study of blood pressure and risk for end-stage renal disease in China. J Am Soc Nephrol 2007;18:1928-1935.

>18 Higashikuni Y, Ishizaka N, Ishizaka Y, Toda E, Nagai R, Yamakado M: Relationship between blood pressure and chronic kidney disease in the Japanese population: the lower the better even in individuals without hypertension? Hypertens Res 2008;31:213-219.
19 Munkhaugen J, Lydersen S, Wideroe TE, Hallan S: Prehypertension, obesity, and risk of kidney disease: 20-year follow-up of the HUNT I study in Norway. Am J Kidney Dis 2009;54:638-646.

20 Clement DL, De Buyzere ML, De Bacquer DA, de Leeuw PW, Duprez DA, Fagard RH, Gheeraert PJ, Missault LH, Braun JJ, Six RO, Van Der Niepen P, O’Brien E: Prognostic value of ambulatory blood-pressure recordings in patients with treated hypertension. N Engl J Med 2003;348:2407-2415.

21 Pickering TG, Hall JE, Appel LJ, Falkner BE, Graves J, Hill MN, Jones DW, Kurtz T, Sheps SG, Roccella EJ: Recommendations for blood pressure measurement in humans and experimental animals. 1. Blood pressure measurement in humans: a statement for professionals from the Subcommittee of Professional and Public Education of the American Heart Association Council on High Blood Pressure Research. Hypertension 2005;45:142-161.

-22 Levey AS, Coresh J, Greene T, Stevens LA, Zhang YL, Hendriksen S, Kusek JW, Van Lente F: Using standardized serum creatinine values in the modification of diet in renal disease study equation for estimating glomerular filtration rate. Ann Intern Med 2006;145:247-254.

23 Schmidt RJ, Baylis C: Total nitric oxide production is low in patients with chronic renal disease. Kidney Int 2000;58:1261-1266.

24 Kim SW, Lee J, Paek YW, Kang DG, Choi KC: Decreased nitric oxide synthesis in rats with chronic renal failure. J Korean Med Sci 2000; 15:425-430.

25 Lyamina NP, Dolotovskaya PV, Lyamina SV, Malyshev IY, Manukhina EB: Nitric oxide production and intensity of free radical processes in young men with high normal and hypertensive blood pressure. Med Sci Monit 2003;9:CR304-CR310.

26 Majid DS, Navar LG: Nitric oxide in the control of renal hemodynamics and excretory function. Am J Hypertens 2001;14:74S-82S.

$\checkmark 27$ Alderton WK, Cooper CE, Knowles RG: Nitric oxide synthases: structure, function and inhibition. Biochem J 2001;357:593-615.

28 Ruan J, Xie Q, Hutchinson N, Cho H, Wolfe GC, Nathan C: Inducible nitric oxide synthase requires both the canonical calmodulin-binding domain and additional sequences in order to bind calmodulin and produce nitric oxide in the absence of free $\mathrm{Ca}^{2+}$. J Biol Chem 1996;271:22679-22686.

29 Vaziri ND, Ni Z, Oveisi F: Upregulation of renal and vascular nitric oxide synthase in young spontaneously hypertensive rats. Hypertension 1998;31:1248-1254.

-30 Kumar U, Chen J, Sapoznikhov V, Canteros G, White BH, Sidhu A: Overexpression of inducible nitric oxide synthase in the kidney of the spontaneously hypertensive rat. Clin Exp Hypertens 2005;27:17-31.
31 Kumar U, Shin Y, Wersinger C, Patel Y, Sidhu A: Diminished expression of constitutive nitric oxide synthases in the kidney of spontaneously hypertensive rat. Clin Exp Hypertens 2003;25:271-282.

32 Suzuki H, Ikenaga H, Hishikawa K, Nakaki T, Kato R, Saruta T: Increases in $\mathrm{NO}^{2-} / \mathrm{NO}^{3-}$ excretion in the urine as an indicator of the release of endothelium-derived relaxing factor during elevation of blood pressure. Clin Sci (Lond) 1992;82:631-634.

$>33$ Dubey RK, Boegehold MA, Gillespie DG, Rosselli M: Increased nitric oxide activity in early renovascular hypertension. Am J Physiol 1996;270:R118-R124.

34 Pearson TA, Mensah GA, Alexander RW, Anderson JL, Cannon RO 3rd, Criqui M, Fadl YY, Fortmann SP, Hong Y, Myers GL, Rifai N, Smith SC Jr, Taubert K, Tracy RP, Vinicor F: Markers of inflammation and cardiovascular disease: application to clinical and public health practice: a statement for healthcare professionals from the Centers for Disease Control and Prevention and the American Heart Association. Circulation 2003;107:499-511.

35 Rizzo M, Corrado E, Coppola G, Muratori I, Mezzani A, Novo G, Novo S: The predictive role of C-reactive protein in patients with hypertension and subclinical atherosclerosis. Intern Med J 2009;39:539-545.

$>36 \mathrm{Xu}$ T, Ju Z, Tong W, Hu W, Liu Y, Zhao L, Zhang Y: Relationship of C-reactive protein with hypertension and interactions between increased C-reactive protein and other risk factors on hypertension in Mongolian people, China. Circ J 2008;72:1324-1328.

37 Mule G, Cottone S, Cusimano P, Riccobene R, Palermo A, Geraci C, Nardi E, Bellavia T, Foraci AC, Cerasola G: The association of microalbuminuria with aortic stiffness is independent of C-reactive protein in essential hypertension. Am J Hypertens 2009;22: 1041-1047.

38 Sung KC, Suh JY, Kim BS, Kang JH, Kim H, Lee MH, Park JR, Kim SW: High sensitivity $\mathrm{C}$-reactive protein as an independent risk factor for essential hypertension. Am J Hypertens 2003;16:429-433.

39 Ridker PM, Hennekens CH, Buring JE, Rifai $\mathrm{N}$ : C-reactive protein and other markers of inflammation in the prediction of cardiovascular disease in women. N Engl J Med 2000; 342:836-843.

40 Kelley-Hedgepeth A, Lloyd-Jones DM, Colvin A, Matthews KA, Johnston J, Sowers MR, Sternfeld B, Pasternak RC, Chae CU: Ethnic differences in C-reactive protein concentrations. Clin Chem 2008;54:1027-1037.

-41 Verma S, Wang CH, Li SH, Dumont AS, Fedak PW, Badiwala MV, Dhillon B, Weisel RD, Li RK, Mickle DA, Stewart DJ: A selffulfilling prophecy: C-reactive protein attenuates nitric oxide production and inhibits angiogenesis. Circulation 2002;106:913-919. 
42 Venugopal SK, Devaraj S, Yuhanna I, Shaul P, Jialal I: Demonstration that C-reactive protein decreases eNOS expression and bioactivity in human aortic endothelial cells. Circulation 2002;106:1439-1441.

-43 Farbom P, Wahlstrand B, Almgren P, Skrtic S, Lanke J, Weiss L, Kjeldsen S, Hedner T, Melander O: Interaction between renal function and microalbuminuria for cardiovascular risk in hypertension: the Nordic Diltiazem Study. Hypertension 2008;52:115-122.

44 Clausen P, Jensen JS, Jensen G, Borch-Johnsen K, Feldt-Rasmussen B: Elevated urinary albumin excretion is associated with impaired arterial dilatory capacity in clinically healthy subjects. Circulation 2001;103:18691874 .
45 Flack JM, Duncan K, Ohmit SE, Quah R, Liu X, Ramappa P, Norris S, Hedquist L, Dudley A, Nasser SA: Influence of albuminuria and glomerular filtration rate on blood pressure response to antihypertensive drug therapy. Vasc Health Risk Manag 2007;3:1029-1037.

46 Siragy HM, Xue C, Webb RL: Beneficial effects of combined benazepril-amlodipine on cardiac nitric oxide, cGMP, and TNF-alpha production after cardiac ischemia. J Cardiovasc Pharmacol 2006;47:636-642.

47 Ghiadoni L, Magagna A, Kardasz I, Taddei S, Salvetti A: Fixed dose combination of perindopril and indapamide improves peripheral vascular function in essential hypertensive patients. Am J Hypertens 2009;22:506-512.
48 Simic DV, Mimic-Oka J, Pljesa-Ercegovac M, Savic-Radojevic A, Opacic M, Matic D, Ivanovic B, Simic T: Byproducts of oxidative protein damage and antioxidant enzyme activities in plasma of patients with different degrees of essential hypertension. J Hum Hypertens 2006;20:149-155.

49 Redon J, Oliva MR, Tormos C, Giner V, Chaves J, Iradi A, Saez GT: Antioxidant activities and oxidative stress byproducts in human hypertension. Hypertension 2003; 41:1096-1101.

50 Chrysohoou C, Panagiotakos DB, Pitsavos C, Skoumas J, Economou M, Papadimitriou L, Stefanadis C: The association between pre-hypertension status and oxidative stress markers related to atherosclerotic disease: the ATTICA study. Atherosclerosis 2007; 192:169-176. 